\title{
Effect of ethanol leaf extract of Telfairia occidentalis on male reproductive activities
}

\author{
Grace Emmanuel Essien 1, Grace Sylvester Effiong 2, ${ }^{*}$, Nse Udoka Ebe 2, Edikan Nkop Enoch 2, and \\ Emmanuel Onyi Nwuzor ${ }^{2}$ \\ ${ }_{1}^{1}$ Department of Pharmacology and Toxicology, Faculty of Pharmacy, University of Uyo, P. M. B. 1017, Uyo, Nigeria. \\ ${ }^{2}$ Department of Biochemistry, Faculty of Basic Medical Sciences, P. M. B. 1017, Uyo, Nigeria.
}

Publication history: Received on 04 December 2020; revised on 13 December 2020; accepted on 15 December 2020

Article DOI: https://doi.org/10.30574/gscarr.2020.5.3.0120

\begin{abstract}
Telfairia occidentalis is a medicinal plant known to exhibit a wide range of biological activities because of the presence of phytochemicals like tannins, saponins, alkaloids, flavonoids and cardiac glycosides. In this research work, the phytochemical screening and the antioxidant activities of Telfairia occidentalis leaves were evaluated. Also, this research work was designed to evaluate the effect of Telfairia occidentalis on reproductive hormones and sexual behaviour in male Albino Wistar rats using standard analytical methods. Twenty-five (25) sexually matured male rats were divided into five (5) groups of five (5) rats each; groups 1 and 2 were the normal and positive controls and were given distilled water and the standard drug (Manix Capsule) respectively while groups 3, 4 and 5 were administered the ethanol extract of the plant in graded dosages of 400,200 , and $100 \mathrm{mg} / \mathrm{kg}$ respectively. Also 12 sexually matured female Albino rats were used for the assessment of sexual behavior.The phytochemical screening revealed the presence of alkaloids, tannins, saponins, terpenes and flavonoids while, the leaves showed a significant free radical scavenging activities with $\mathrm{IC}_{50} 90 \mu \mathrm{g} / \mathrm{ml}$. The hormonal result showed that the extract cause a dose dependent significant increase $(\mathrm{p}<0.05)$ in testosterone when compared with the normal control. However, there was a significant decrease $(\mathrm{p}<0.05)$ in serum luteinizing hormone ( $\mathrm{LH})$ and follicle-stimulating hormone (FSH) levels also in comparison with the normal control. In conclusion, the ethanol leaf extract of Telfairia occidentalis increases the reproductive hormones which might increase the reproductive activities of the male rats.
\end{abstract}

Keywords: Telfairia occidentalis; Medicinal plants; Phytochemicals; Antioxidant activities; Sexual behavior; Reproductive hormones

\section{Introduction}

The use of medicinal plants to treat human diseases has been in practice since antiquity. According to WHO, $80 \%$ of the world population depends on medicinal plants, while only $20 \%$ use medications prescribed by physicians [1].

Telfairia occidentalis, named after an Irish botanist, Charles Telfair (1778 - 1833) is a medicinal plant of the Cucurbitaceae family, which consists mostly of herbs or rarely under shrub with water juice. It is a tropical vine grown in West Africa and highly reputed in traditional medicine [2]. The plant is commonly called Fluted pumpkin. Locally, it is known as Ubong in Efik and Ibibio, Ugwu in Igbo, Ewe Aworoko in Yoruba [3].

Reproduction is the biological process by which new individual organisms "offspring" - are produced from their "parents". Humans are sexually dimorphic; however, both male and female reproductive systems consist of different

*Corresponding author: Grace Sylvester Effiong; Phone Number; 08063222797. E-mail; graceffiong2007@yahoo.com Mailing address of correspondence author: Department of Biochemistry, Faculty of Basic Medical Sciences, P. M. B. 1017, Uyo, Nigeria. 
sets of structures, that is, gonads, internal genitalia, and external genitalia [4]. Development and differentiation of the specialized cells, tissue, and structures that comprise the male reproductive system already start in utero but only initiate function during puberty [4].

A hormone is any member of a class of signaling molecules produced by glands in multicellular organisms that are transported by the circulatory system to target distant organs to regulate physiology and behavior [5]. Hormones play a big part in the development of both primary and secondary sexual characteristics in male humans and animals [6].

Antioxidants are man-made or natural substances that may prevent or delay some types of cell damage. Antioxidants are found in many foods, including fruits and vegetables. Although oxidation reactions are crucial for life, they can also be damaging; plants and animals maintain complex systems of multiple types of antioxidants, such as glutathione, vitamin C, vitamin A, and vitamin E as well as enzymes such as catalase, superoxide dismutase and various peroxides [7].

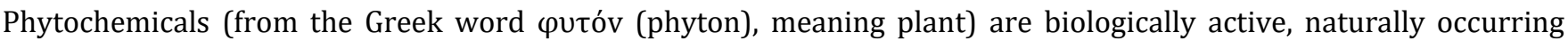
chemical compounds found in plants, which provide health benefits for humans further than those attributed to macronutrients and micronutrients, examples include the following: alkaloids, tannins, cardiac glycosides, flavonoids, terpenes, saponins, quinonesetc [8].

T. occidentalis is consumed in several countries including Nigeria since it is an important staple vegetable. Minerals rich in the leaves are calcium, potassium, sodium, phosphorus and magnesium. Also found in the leaves of T. occidentalis include; vitamins (such as thiamine, riboflavin, nicotinamide, ascorbic acid, retinol and tocopherol) antioxidants, iron and phytochemicals such as flavonoids, phenols and tannins, [9] [10] [11]. It has a high profile of aminoacids which include; alanine, aspartate, glycine, glutamine, histidine, lysine, methionine, tryptophan, cystine, leucine, arginine, serine, threonine, phenylalanine, valine, tyrosine and isoleucine [12][9]. In view of these profertility components of $T$. occidentalis, this study is aimed at determining the effects of ethanol leaf extract of Telfairia occidentalis on male reproductive activities.

\section{Material and Methods}

\subsection{Collection and Identification of Plant Sample}

Telfairia occidentalis was purchased from Itam market in Akwa Ibom State, Nigeria in May, 2018. The plant was identified and authenticated by Prof. (Mrs.) Uduak Eshiet; a taxonomist of the Department of Botany and Ecological Studies, Faculty of Science, University of Uyo, Nigeria. It was given the Voucher Number UUPH 1 (b) and was deposited at the Department of Pharmacognosy and Natural Medicine, Faculty of Pharmacy Herbarium, University of Uyo, Nigeria.

\subsection{Preparation and Extraction of Plant Material}

The wet method of extraction was used for the extraction. The leaves were plucked from the plant stalk, thereafter the leaves were washed and drained to remove the debris, and then $500 \mathrm{~g}$ weight of the leaves were cut into pieces and immersed in 2.5L of 70\% ethanol and kept in an amber colored bottle for 72 hours. At the end of the three days the mixture was filtered using a cheese cloth and then with Whatman No.1 filter paper. The filtrate was then put in a beaker and kept in a water bath at $30-40^{\circ} \mathrm{C}$, it yielded $25 \mathrm{~g}$ of extract and stored in a refrigerator at $40 \mathrm{C}$ until needed for analysis.

\subsection{Experimental Animals}

Twenty-five male and 12 female Albino Wistar rats weighing 150-200g were used in this study. The rats were bought from the University of Port Harcourt, Nigeria and brought to the University of Uyo, Nigeria where the research took place. The animals were kept in wooden cages with wire mesh top and maintained under standard conditions of humidity $(50 \pm 5 \%)$ and temperature $(28 \pm 20 \mathrm{C})$ and maintained in a $12 \mathrm{hours}$ light/dark cycle. They were given feeds and water ad libitum and were acclimatized for 14 days before the commencement of the work. The handling of the animals was approved by the Animal Ethical Committee of the University of Uyo, Uyo, Nigeria.

\subsection{Experimental Design}

The animals were divided into five groups of five rats each and treated as shown on Table 1. Group I was the positive control and administered the standard drug (Manix capsule) at a dose of $9.0 \mathrm{mg} / \mathrm{kg}$, group II was the normal control and given $5 \mathrm{ml}$ of distilled water while groups III, IV and V were administered the extract at a dose of $400 \mathrm{mg} / \mathrm{kg}, 200 \mathrm{mg} / \mathrm{kg}$ and $100 \mathrm{mg} / \mathrm{kg}$ respectively. All the administration was done by oral route and it lasted for 14 days. Fourty-eight hours 
before the last day of administration, $17, \beta$-estradiol was administered to 12 selected females animals subcutaneously to induce estrous and enable vaginal opening; furthermore 8 hours before the mating experiment was carried out, progesterone was also administered to these 12 selected female animals subcutaneously to allow for mating to occur on the last day of administration when mounting would be done.

Table 1: Experimental Design

\begin{tabular}{|l|l|l|l|}
\hline Groups & No. of Animals & Treatment & Dosage \\
\hline I (Positive control) & 5 & Manix capsule & $9.0 \mathrm{mg} / \mathrm{kg}$ \\
\hline II (Normal control) & 5 & Distilled water & $5 \mathrm{ml}$ \\
\hline III (High dose) & 5 & Crude extract of Telfairia occidentalis & $400 \mathrm{mg} / \mathrm{Kg}$ \\
\hline IV (Medium dose) & 5 & Crude extract of Telfairia occidentalis & $200 \mathrm{mg} / \mathrm{Kg}$ \\
\hline V (Low dose) & 5 & Crude extract of Telfairia occidentalis & $100 \mathrm{mg} / \mathrm{Kg}$ \\
\hline
\end{tabular}

\section{Results and Discussion}

\subsection{Phytochemical Screening of Telfairia occidentalis Leaves}

The phytochemical screening of ethanol extract of Telfairia occidentalis as shown in the Table 2, revealed the presence of the following secondary metabolites: alkaloids, flavonoids, saponins, tannins, terpenes, free anthraquinones and combined anthraquinones.

\subsection{Antioxidant Activity of Telfairia occidentalis Leaves}

The free radical scavenging activities of extract and fractions are as shown in Table 3. The result showed that the crude ethanol leaf extract had a significant free radical scavenging activity, with $\mathrm{IC}_{50}$ of $90 \mu \mathrm{g} / \mathrm{ml}$ when compared to the IC $\mathrm{C}_{50}$ of $110 \mu \mathrm{g} / \mathrm{ml}$ in ascorbic acid.

Table 2: Phytochemical Screening of Telfairia occidentalis Leaf Extract

\begin{tabular}{|l|l|l|}
\hline \multicolumn{1}{l}{ Test } & Cream precipitate & ++ \\
\hline Alkaloids & Brown ring & + \\
\hline Keller-Kiliani & Yellow colouration & ++ \\
\hline Flavonoids & Persistent foaming & + \\
\hline Saponins & Dark green color & ++ \\
\hline Tannins & Reddish-brown colour & + \\
\hline Terpenoids & Pink colouration & + \\
\hline Free Anthraquinones & Pink colouration & + \\
\hline Combined Anthraquinones & No deposition of red precipitate & - \\
\hline Phlobatannins & Key; - absent, + trace, ++ positive. & \\
\hline
\end{tabular}


Table 3: Antioxidant Activity of Telfairia occidentalis Leaves

\begin{tabular}{|c|c|c|c|c|}
\hline Group & Conc. $(\mu \mathrm{g} / \mathrm{ml})$ & Absorbance $(517 \mathrm{~nm})$ & $\%$ Inhibition & $\mathrm{IC}_{50}$ \\
\hline \multirow[t]{6}{*}{ Ethanol extract } & Control & $1.167 \pm 0.003$ & 0 & \multirow[t]{6}{*}{$90 \mu \mathrm{g} / \mathrm{ml}$} \\
\hline & 15.625 & $1.128 \pm 0.002$ & 23.34 & \\
\hline & 31.25 & $0.995 \pm 0.004$ & 34.70 & \\
\hline & 62.50 & $0.676 \pm 0.003$ & 42.10 & \\
\hline & 125.00 & $0.317 \pm 0.002$ & 72.80 & \\
\hline & 250.00 & $0.139 \pm 0.001$ & 88.10 & \\
\hline \multirow{6}{*}{$\begin{array}{l}\text { Standard } \\
\text { (Ascorbic acids) }\end{array}$} & Control & $1.368 \pm 0.001$ & 0 & \multirow[t]{6}{*}{$110 \mu \mathrm{g} / \mathrm{ml}$} \\
\hline & 15.625 & $0.468 \pm 0.001$ & 6.20 & \\
\hline & 31.25 & $0.445 \pm 0.001$ & 10.80 & \\
\hline & 62.50 & $0.353 \pm 0.001$ & 29.30 & \\
\hline & 125.00 & $0.208 \pm 0.002$ & 58.30 & \\
\hline & 250.00 & $0.092 \pm 0.001$ & 81.60 & \\
\hline
\end{tabular}

\subsection{Male Reproductive Hormones in Telfairia occidentalis Leaves}

The male reproductive hormones found in $T$. occidentalis were; testosterone, Luteinizing hormone and follicle stimulating hormone as shown on Figs. 1, 2 and 3

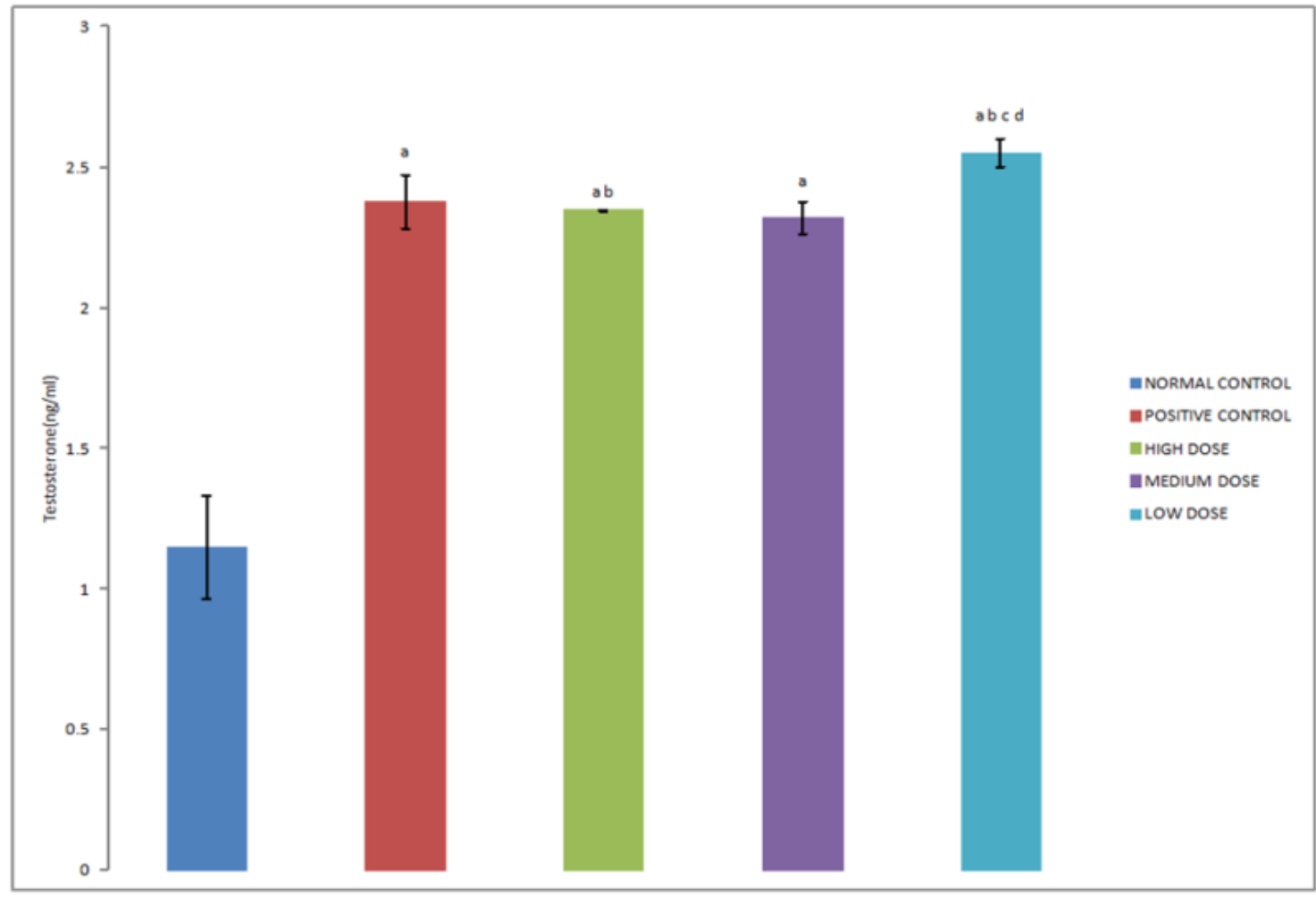

Figure 1: Effect of Ethanol Extract of Telfaiaria occidentalis Leaf on Testosterone 


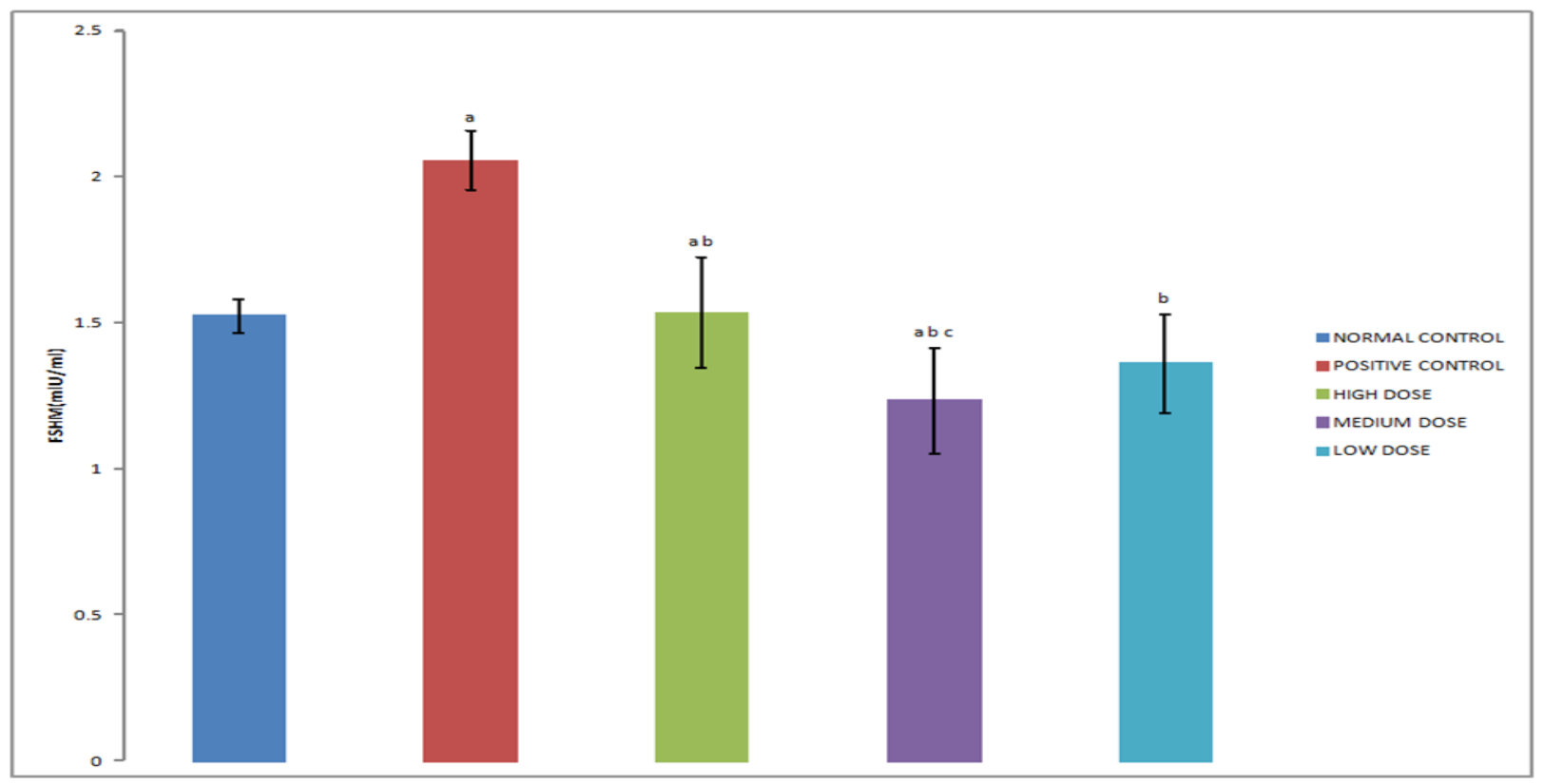

Figure 2: Effect of Ethanol Extract of Telfaiaria occidentalis Leaf on Follicle Stimulating Hormone

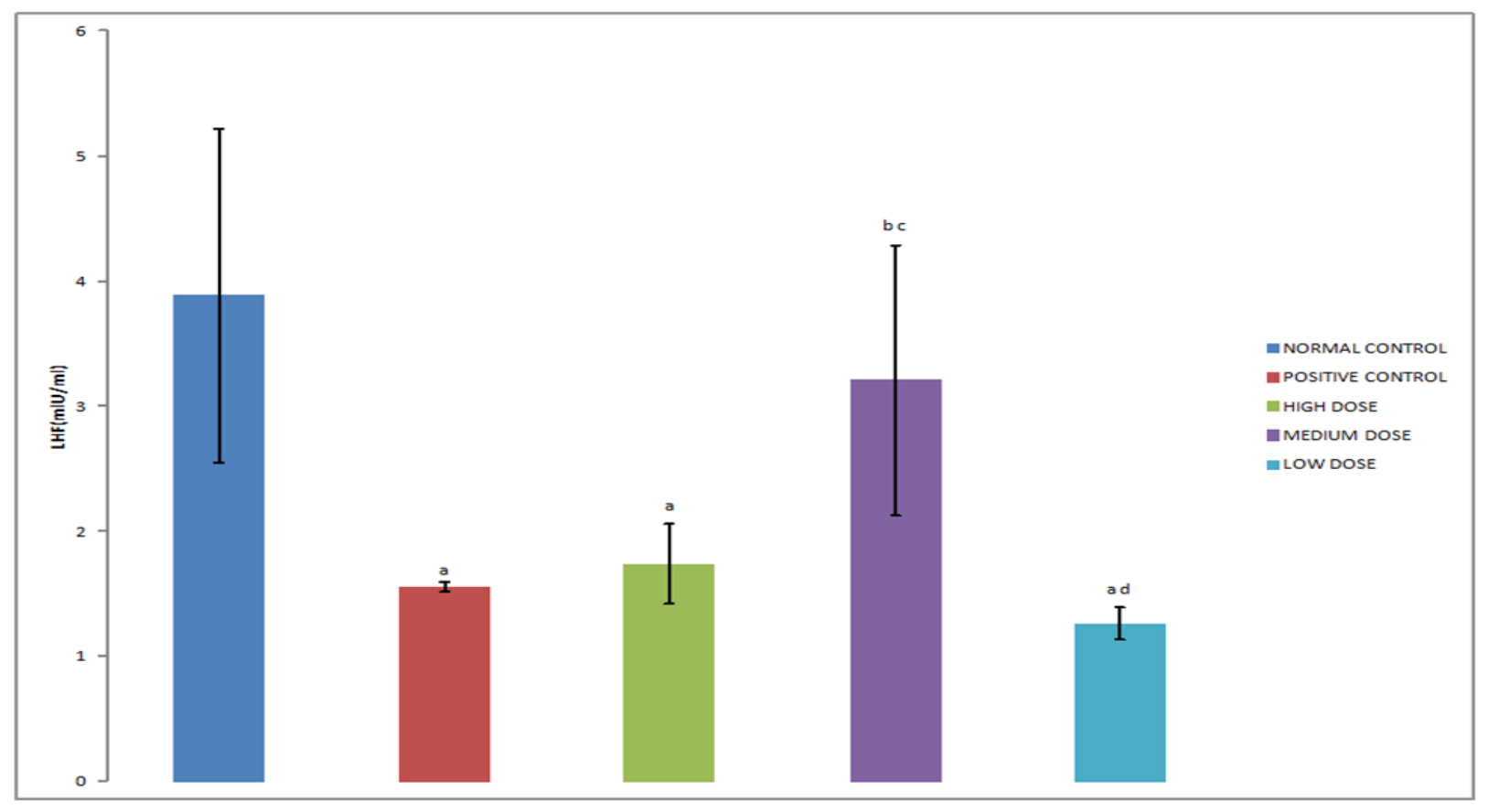

Figure 3: Effect of Ethanol Extract of Telfaiaria occidentalis Leaf on Luteinizing Hormone

\subsection{Male Sexual Behaviour with Telfairia occidentalis Leaves}

Sexual behavior activity frequencies - Ejaculatory Frequency (EF), Mount Frequency (MF), and Intromission Frequency (IF) were significantly increased (P $\geq 0.005)$; Penile Erection Latency (PEL), Ejaculatory Latency (EL), Intromission Latency (IL), Mount Latency (ML) and Penile Erection (PE) were significantly reduced (P $\geq 0.005$ ) as shown in Figs. 4, 5, $6,7,8,9,10$ and 11 respectively. 


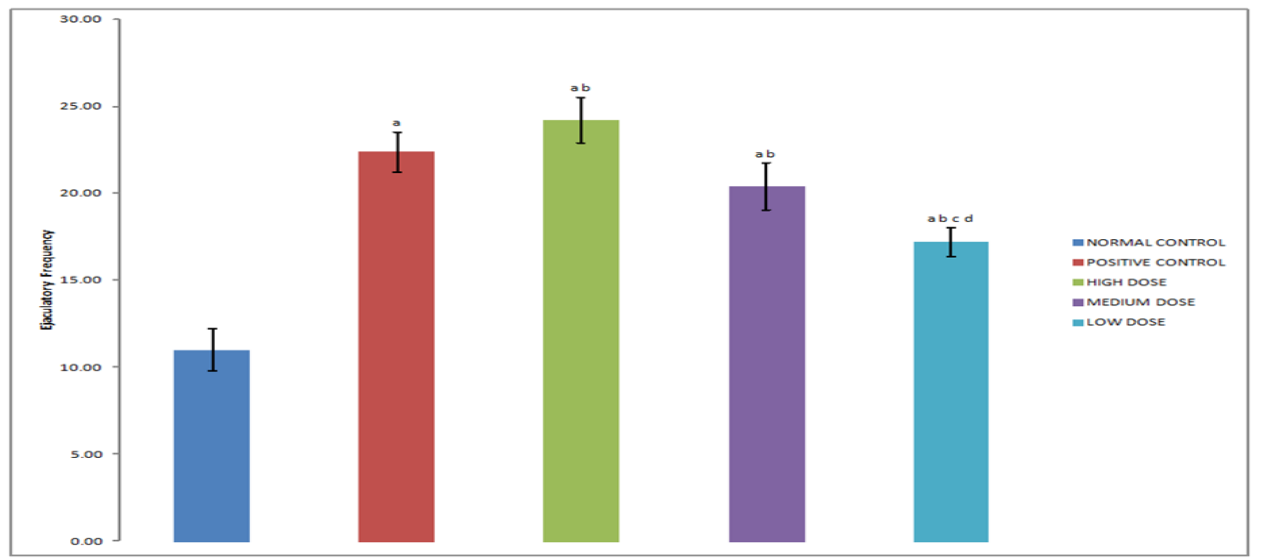

Figure 4: Effect of Ethanol Extract of Telfaiaria occidentalis Leaf on Ejaculatory Frequency

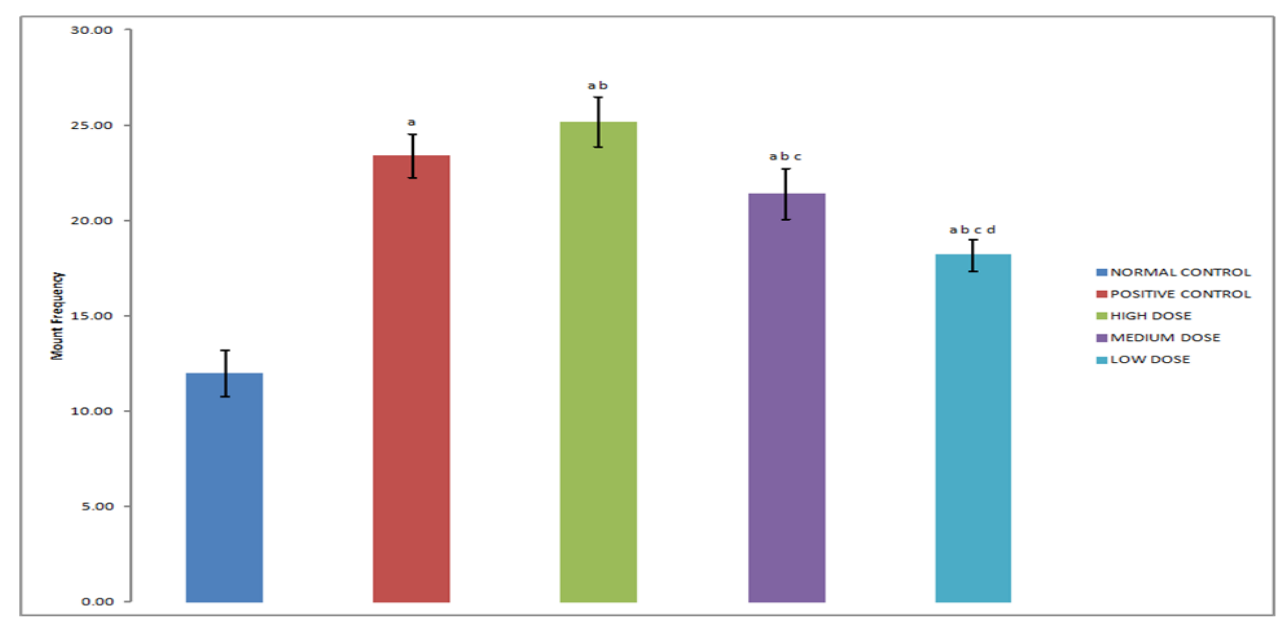

Figure 5: Effect of Ethanol Extract of Telfairia occidentalis Leaf on Mount Frequency

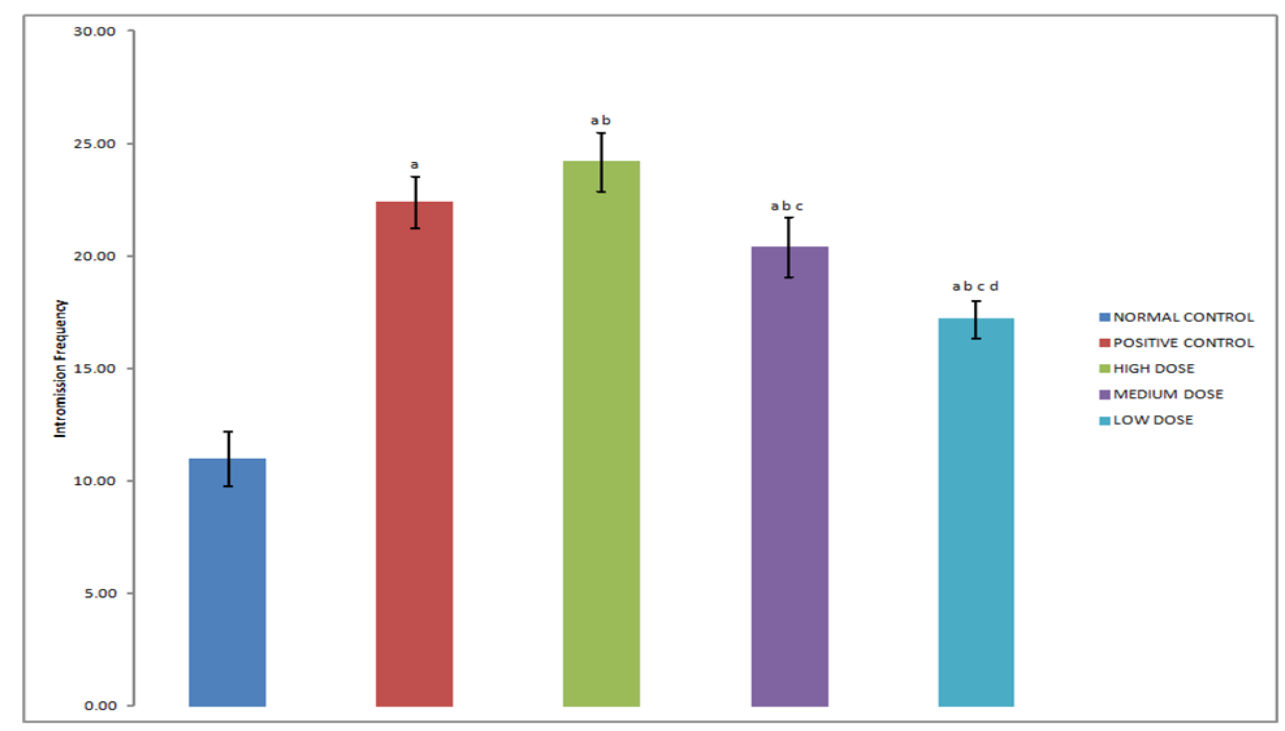

Figure 6: Effect of Ethanol Extract of Telfairia occidentalis Leaf on Intromission Frequency 


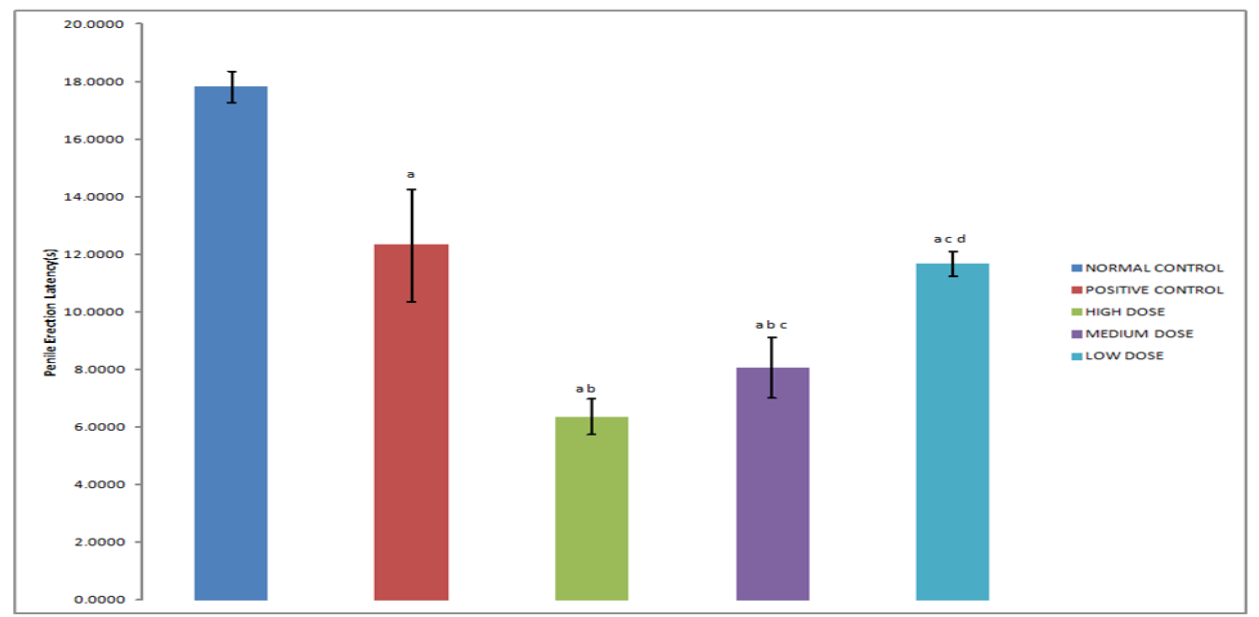

Figure 7: Effect of Ethanol Extract of Telfairia occidentalis Leaf on Penile Erection Latency

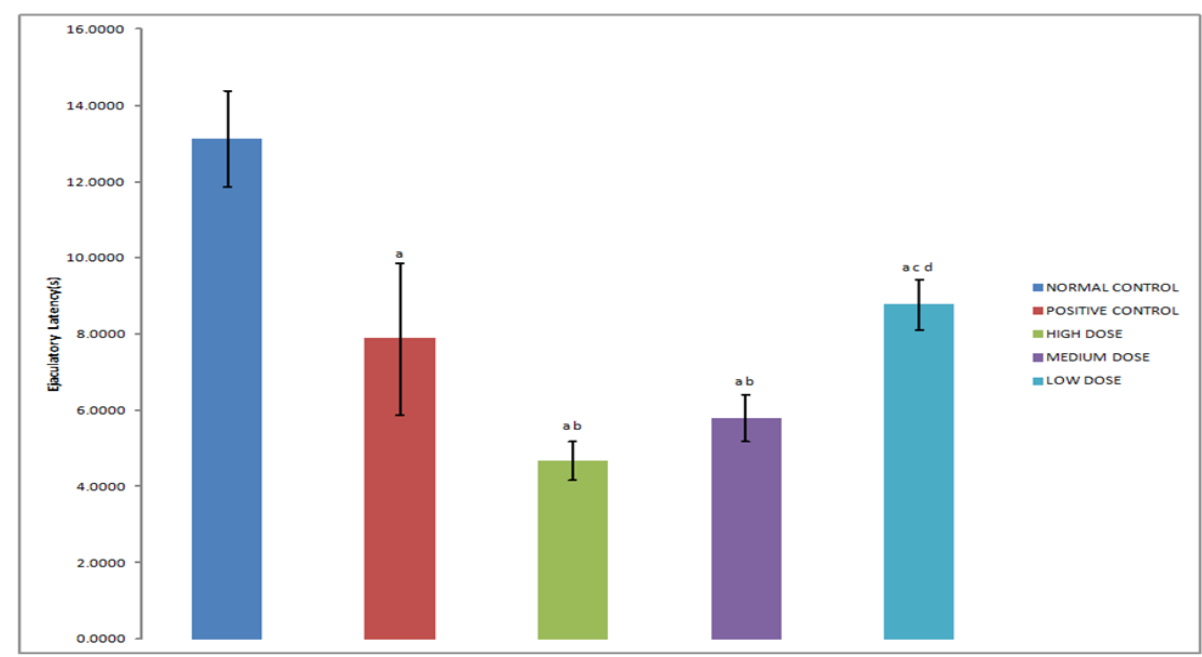

Figure 8: Effect of Ethanol Extract of Telfairia occidentalis Leaf on Ejaculatory Latency

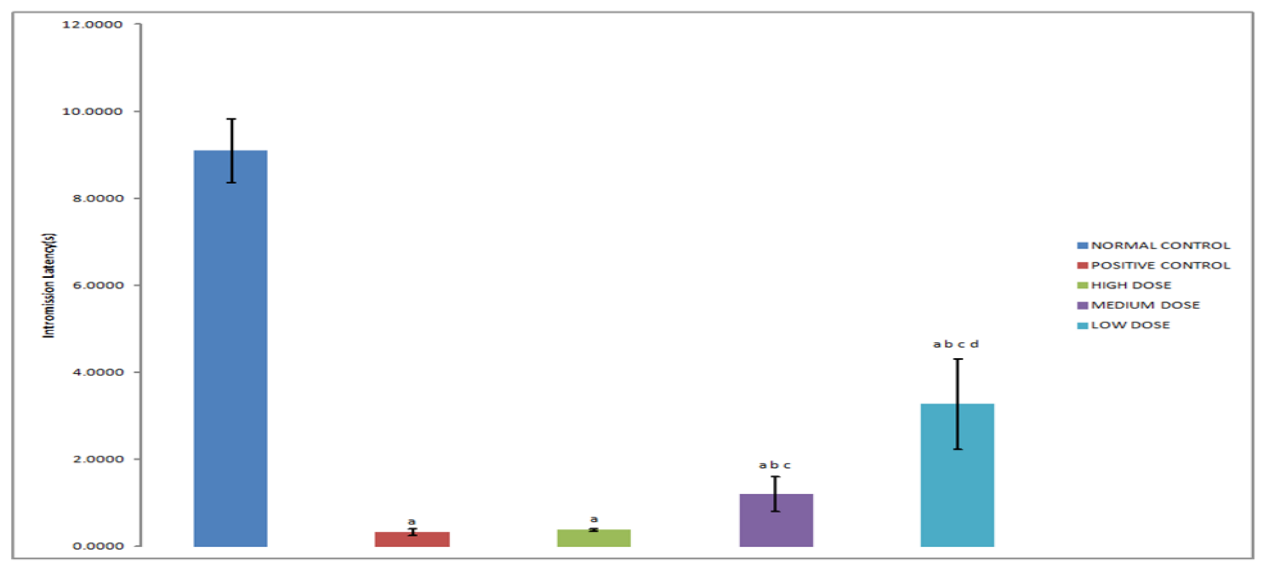

Figure 9: Effect of Ethanol Extract of Telfairia occidentalis Leaf on Intromission Latency 


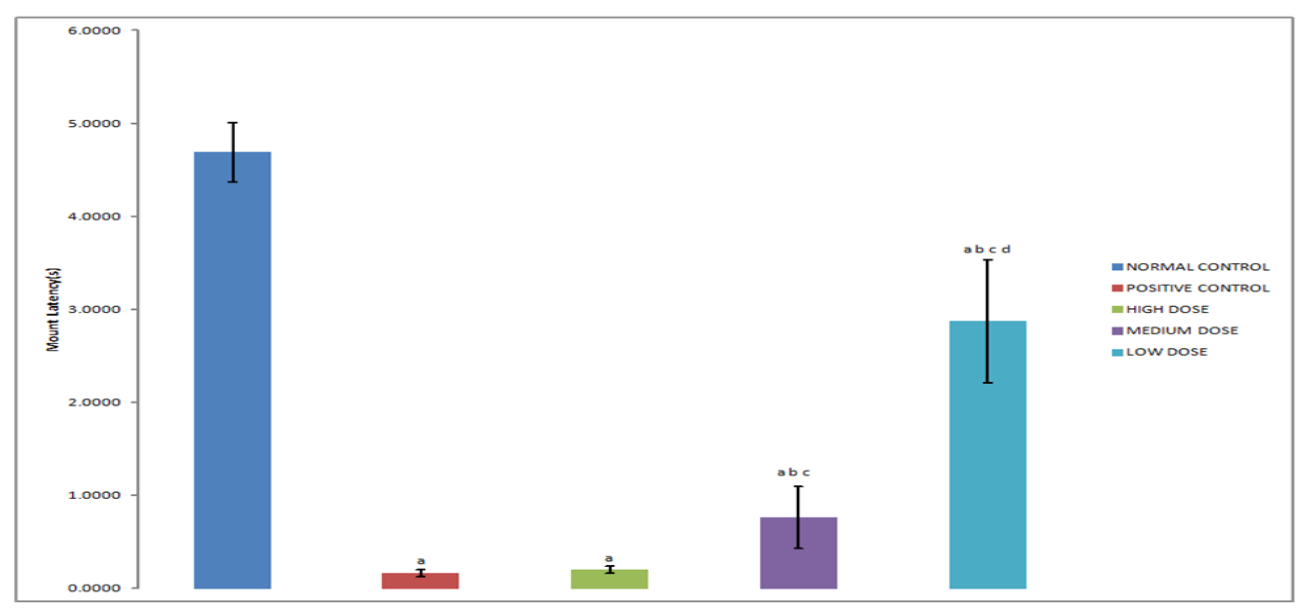

Figure 10: Effect of Ethanol Extract of Telfairia occidentalis Leaf on Mount Latency

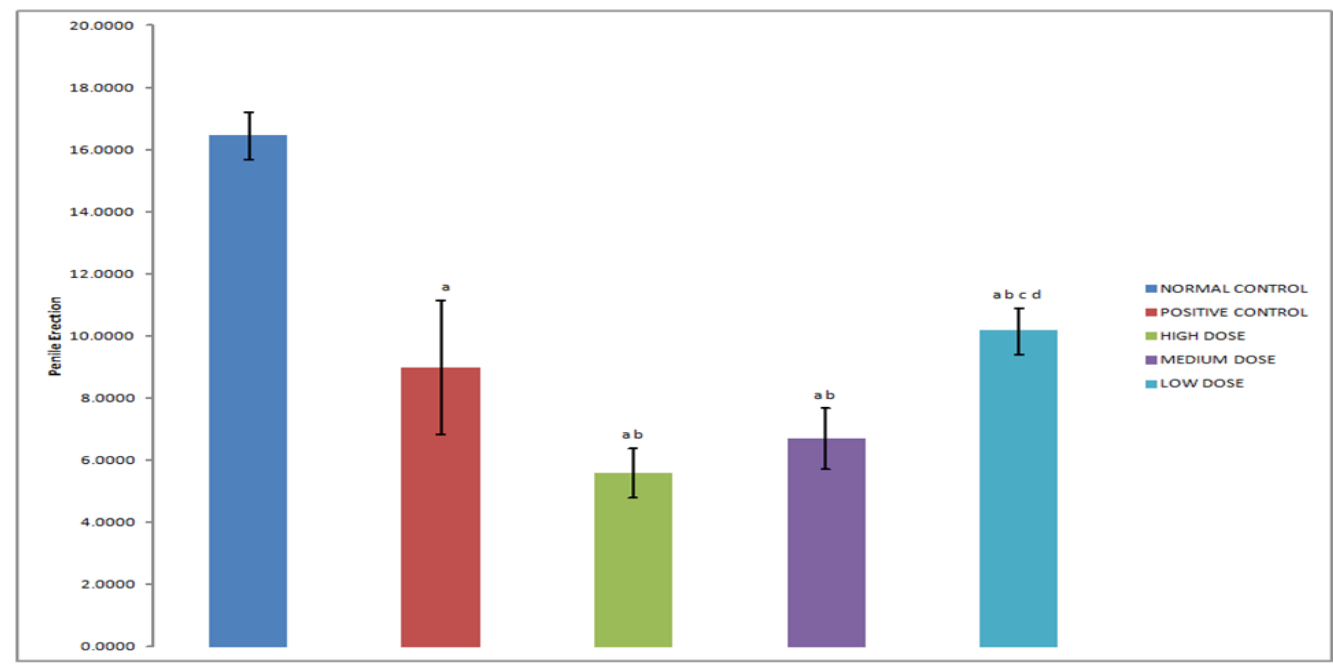

Figure 11: Effect of Ethanol Extract of Telfairia occidentalis Leaf on Penile Erection

\section{Discussion}

The phytochemical screening of T. occidentalis reveals the presence of the following secondary metabolites: alkaloids, flavonoids, saponins, tannins, terpenes, free anthraquinones and combined anthraquinones. However, phlobatannins was absent which was in consonance with the works of [13][14][15][16][17][18] who also reported the present of these phytochemicals in T. occidentalis in their works.

The results of the DPPH free radical scavenging activity of the crude ethanol leaf extract of Telfairia occidentalis showed that the crude ethanol leaf extract possessed significant free radical scavenging activity, with an $\mathrm{IC}_{50} \mathrm{value} \mathrm{of} 90 \mu \mathrm{g} / \mathrm{ml}$. Comparison of obtained $\mathrm{IC}_{50}$ value of ascorbic acid $110 \mu \mathrm{g} / \mathrm{ml}$ indicated that the crude extract exhibited higher antioxidant activity than the standard which was ascorbic acid. These antioxidants have also been reported present in Telfairia occidentalis (T. occidentalis) in the work of [9]. Antioxidants such as flavonoids, ascorbic acid and tocopherol have been reported to significantly reduce oxidative stress and improve sperm parameters [19] [20].

Aphrodisiacs are substances that enhance sexual drive/sexual pleasure and can arouse sexual desire or libido [21]. They are substances that can be used to modify impaired sexual functions. In male rats, the extract caused a marked change in sexual behavior. There was significant decrease in mount latency, with a corresponding increase in mount frequency, suggesting an enhanced arousal and sexual vigor. There was also decrease in intromission latency and increase in intromission frequency an indicative of suggested increased copulation rate. These indices of libido, when taken together pointed to the fact that the extract could possess aphrodisiac properties. Such increases in the frequencies of 
mount, intromission and ejaculation, suggest that libido, sexual vigor and sexual performance were enhanced which was in consonance to the work of [22]. These effects could further be strengthened by the action of the extract in causing increase in the serum testosterone level.

It is a known fact that sexual behavior and erection depend on an androgen which may be acting both centrally and peripherally. Peripherally, testosterone has cytosolic receptors, which when activated lead to a sequence of reactions that enhance libido [23]; so almost all men will find that their libido is improved by testosterone [23] as seen in the rats treated with Telfairia occidentalis in this research.

Male reproductive hormones which include; testosterone, follicle-stimulating hormone and luteinizing hormone were assayed biochemically and from the result gotten, the testosterone levels showed a significant difference which is dose dependent based on the extract, with a significant increase noted on the low dose of the extract when compared to the control groups and also in the high and medium dose of the extract. This is in tandem with the work of [24]. This shows that when the Telfairia occidentalis leaf extract was administered at low dosages, it tends to boost up the levels of testosterone compared to the other dosage of the extract and the controls.

In terms of the follicle-stimulating hormone, the positive control which was the standard drug showed a significant increase in serum levels of the hormone when compared to the normal control and the extract dosage; this suggest that the normal control and extract could boosts the level of the male reproductive hormone - follicle-stimulating hormone when compared to the standard drug.

Luteinizing hormone levels showed a significant increase in normal control group when compared to the positive control and extract groups. This shows that both the standard drug and the extract reduced the levels of luteinizing hormone significantly when compared to the normal control in this study. The findings in this present study on hormone profiles showed significant rise in testosterone among the treated rats with associated increase in the levels of gonadotropins (LH and FSH) which is in consonance with the reports of [25][26][27].

\section{Conclusion}

This research suggest that the ethanol leaf extract of Telfairia occidentalis could enhance indices that favor sexual drive and vigor by increasing mount and intromission frequencies while decreasing mount and intromission latencies; thereby improving sexual behavior in the male- an indicative of its aphrodisiac potentials. The extract also significantly increased the serum testosterone concentration in the male rats, thus it could have enhanced libido since testosterone is the principal sex hormones in males. Testosterone is an anabolic steroid that plays a key role in the development of male reproductive tissues such as testes and prostate. Therefore, the extract when it undergoes further research could serve as drug for combating infertility in males.

\section{Compliance with ethical standards}

\section{Acknowledgments}

We acknowledge the technical advice of the laboratory technologists Mrs. Sifon and Mr. Bala Danladi is highly appreciated.

\section{Disclosure of conflict of interest}

The authors have no conflict of interest among them.

\section{Statement of ethical approval}

The handling of the animals was approved by the Animal Ethical Committee of the University of Uyo, Uyo, Nigeria. Thus, the work was done with the guidelines of the Ethical Committee.

\section{References}

[1] World Health Organization. World health statistics: monitoring health for the SDGs, sustainable development goals. World Health Organization, 2017. 
[2] G Oboh, EE Nwanna, CA Elusiyan. Antioxidant and Antimicrobial Properties of Telfairia occidentalis(Fluted pumpkin) Leaf Extracts. Journal of Pharmacology \& Toxicology. 2010; 5 (8): 539-547.

[3] Alada ARA. The haematological effect of Telfairia occidentalis diet preparation. African Journal of Biomedical. 2000; 3: 185-186.

[4] Radu A, Pichon C, Camparo P, Antoine M, Allory Y, Couvelard A, Fromont G,Hai MT, Ghinea N. Expression of follicle-stimulating hormone receptor in tumor blood vessels. National English Journal of Medicine. 2010; 363 (17): 1621-1630.

[5] Luetjens C. MandWeinbauer GF. Chapter 2: Testosterone: Biosynthesis, transport, metabolism and) nongenomic) actions. In Nieschlag E, Behre HM, Nieschlag S. Testosterone: Action, Deficiency, Substitution (4th ed.). Cambridge: Cambridge University Press. 2012; 15-32.

[6] Jiang X, Dias JA, He X. Structural biology of glycoprotein hormones and their receptors: insights to signaling". Molecular and Cellular Endocrinology. 2014; 382(1): 424-451.

[7] Csepregi K, Neugart S, Schreiner M, Hideg É. Comparative evaluation of total antioxidant capacities of plant polyphenols. Molecules. 2016; 21(2): 208.

[8] Khoddami A. Techniques for analysis of plant phenolic compounds. Molecules. 2013; 18 (2): $2328-2375$.

[9] Fasuyi AO. Nutritional potentials of some tropical vegetable leaf meals. Chemical characterization and functional properties. Afr. J. Biotechnol. 2006; 5:49-53.

[10] Horsfall M, Jr, Spiff IA. Equilibrium sorption study of Al, Co3+ and Ag2+ in aqueous solution of fluted pumpkin (Telfairia occidentalis Hook f) waste biomass. Acta Chimica. Slovenica. 2005; 52:174-181.

[11] Oboh G, Nwanna EE, Elusiyan CA. Antioxidant and Antimicrobial Properties of Telfairia occidentalis (Fluted pumpkin) Leaf Extracts. J. Pharmacol. Toxicol. 2006; 1(2): 167-175.

[12] Omale J, Okafor P. Cytotoxicity and antioxidant screening of some selected Nigerian medicinal plants. Asian J. Pharmaceut. Clin. Res. 2009; 2(4): 48 - 53.

[13] Ogunlesi M, Okiei W, Azeez L, Obakachi V, Osunsanmi O, Nkechor G. Vitamin C content of tropical vegetable and food determined by voltametric and titrimetric methods and their relevance to the medicinal uses of the plant. Int. J. Electrochem. Sci. 2010; 5: 105-115.

[14] Kayode, AA, Kayode OT. Some Medicinal Values of Telfairia occidentalis: A review. Amer. J. Biochem. Molecular Biol. 2010; 1: 30-38.

[15] Kayode AAA, Kayode OT. Some medicinal values of Telfairia occidentalis: a review. Am. J. Biochem. Mol. Biol. 2011; 1:30-38.

[16] Tindall HD. Istedn. Oxford University Press; Oxford, Uk: 1968; Commercial Vegetable Growing.

[17] Das S, Parveen S, Kundra CP, Pereira BMJ. Reproduction in male rats is vulnerable to treatment with the flavonoid-rich seed extracts of Vitex Negundo Phytother. Res. 2004; 18:8-13.

[18] Lee K, Dabrowski K. Long-term effects and interactions of dietary vitamins C and E on growth and reproduction of yellow perch, Percaflavescens. Aquaculture. 2004; 230: 377-389.

[19] Das S, Parveen S, Kundra CP, Pereira BMJ. Reproduction in male rats is vulnerable to treatment with the flavonoid-rich seed extracts of Vitex Negundo Phytother. Res. 2004; 18:8-13.

[20] Lee K, Dabrowski K. Long-term effects and interactions of dietary vitamins C and E on growth and reproduction of yellow perch, Percaflavescens. Aquaculture. 2004; 230:377-389.

[21] Gauthaman K, Adaikan PG, Prasad RNV. Aphrodisiac properties of Tribulus terrestris extract (Protodioscin) in normal and castrated rats. Life Sci. 2002; 71(12): 1385-1396.

[22] Ratnasooriya WD, Dharmasiri MG. Effects of Terminaliacatappa seeds on sexual behavior and fertility of male rats. Asian Journal of Andrology. 2000; 2: 213-226.

[23] Hull EM, Du J, Lorrain DS, Matuszewich L. Extracellular dopamine in the medial preoptic area: implications for sexual motivation and hormonal control of copulation. J. Neurosci 1995; 15: 7465-7471.

[24] Christopher SL, Ejuoghanran OSO, Festus OA. Profertility effects of aqueous leaf extract of Telfairia occidentalis in adult male Wistar rats. J Exp. Clin. Anat. 2015; 14:88-94. 
[25] Oyeyemi M, Leigh 0, Ajala 0, Badejo A, Emikpe B. The effects of the aqueous extract of 'ugu' (Telfairia occidentalis) leaves on the testis and spermatozoa characteristics in the male Albino rat. Folia Veter. 2008; 52 (2): $102-105$.

[26] Salman TM, Olayiki LA, Oyeyemi WA. Effects of the aqueous extracts of Telfairia occidentalis on some hematological reproductive indices and blood glucose. Afr J Biotechnol. 2008; 7: 2299-303.

[27] Saalu LC, Kpela T, Benebo AS, Oyewopo AO, Anifowope EO, Oguntola A. The dose-dependent testiculo protective and testiculotoxic potentials of Telfairia occidentalis Hook f. leaves extract in rat. Int. J. Appl. Res. Nat. Prod. 2010; 3:27-38. 